\title{
OBTAINING BOILER FUEL GAS TO REDUCE AIR POLLUTION: THE POLICY OF THE FEDERAL POWER COMMISSION
}

\author{
BarRy D. REIN*
}

\section{INTRODUCTION}

Public utilities, particularly those operating steam-electric generating plants, contribute substantially to atmospheric pollution. The extent of their contributions may be affected in any given instance by the location of the plant, the type of generating unit, the particular fuel or fuels burned, the existence of pollution control equipment, and the scheduling of particular fuels in multi-fuel plants. One or more of these factors may fall within the purview of regulatory agencies of the federal, state, and local governments. This article deals with an aspect of utilities regulation of particular importance: the jurisdiction of the Federal Power Commission (FPC) over the use by steam-electric generating utilities of natural gas for boiler fuel, for the purpose of reducing air pollution produced by burning alternative fuels.

In 1938 the FPC was given responsibility for administering the federal part of a comprehensive federal-state regulatory scheme intended to assure that natural gas, a wasting asset, would be allocated to uses consistent with the public interest at minimum cost to the consumer. Through the years this broad directive has been narrowed to an inquiry into particular criteria which purport to embody the public interest. Attempts in recent years to add to this list of criteria the impact of a requested fuel use change on air pollution have met with less than complete success. The problem sought to be mitigated by these attempts-utilities' contributions to atmospheric pollution-is not likely to be solved in the immediate future other than by increased allocations of gas to replace coal and oil as boiler fuel. However, other solutions, particularly nuclear power generation, are visible somewhat further ahead. Consequently, until these alternative solutions are found or implemented, it is likely that increasing pressure will be brought to bear upon the Commission to certificate boiler fuel gas. Where certification can be shown to have a significant impact on air pollution, such pressure may ultimately result in a reversal of the Commission's present unreceptiveness to air pollution arguments.

- B.S. 196x, Massachusetts Institute of Technology; LL.B. I965, Georgetown University. Associate in the firm of Pennie, Edmonds, Morton, Taylor \& Adams, New York City. Counsel, Citizens for Clean Air, Inc., New York City.

The writer wishes to express his appreciation to Robert F. Ebin, Esq., of counsel for Citizens for Clean Air, Inc., before the Federal Power Commission in Transcontinental Gas Pipe Line Corp. (Phase II), for his valuable assistance in the preparation of this article. 


\section{The Effect of Steam-Electric Generation on Air Poliution}

Generation of electrical power by fossil fuels invariably produces pollutants; the particular pollutants produced and their rates of production vary with different fuels. The important fossil fuels (burned under boilers to make steam used to run turbine generators) are oil, coal, and natural gas. ${ }^{1}$

Coal and oil in burning produce fly ash, soot, and grime (euphemistically known collectively as "particulate matter"), hydrocarbons, carbon monoxide, sulfur oxides (sulfur dioxide and sulfur trioxide), nitrogen oxides, and other pollutants. Sulfur oxides and particulates, primarily, are relevant to the present discussion since they are the significant pollutants produced by burning coal and oil. Natural gas, in contrast, produces no particulates, is virtually sulfur-free, and yields no significant amounts of other pollutants. This fact has resulted in pressure upon the FPC, which has jurisdiction over interstate transportation and sale of natural gas, to license the provision of quantities of gas to replace coal and oil as boiler fuel. However, in the several proceedings which have been brought to obtain gas for boiler fuel, the Commission has generally taken the position that the advantage to be gained by way of reducing air pollution does not outweigh other factors militating against granting the gas.

For an indication of the potential benefit to be obtained by substituting gas for coal or oil, consider that in 1965 the average sulfur oxide emissions of Consolidated Edison Company ("Con Ed") in New York City ${ }^{2}$ amounted to 789 tons per day$3^{6 r} .9$ tons due to coal burning and 427.I tons due to oil. ${ }^{3}$ In total, Con Ed contributed about half (300,000 tons) of the total sulfur dioxide emitted into New York's atmosphere in 1965 . Of slightly over 95,000 tons of particulates emitted into New York City's atmosphere in $\mathrm{xg} 66$, power generation accounted for twenty-one per cent. ${ }^{4}$

The importance of the utilities' role in polluting a given atmosphere depends upon the importance of sulfur oxides in the area's over-all pollution picture. Climate, topography, meteorology, industrial concentration, and many other factors affect a city's pollution mix. In Los Angeles, for example, where space heating (a major

\footnotetext{
${ }^{1}$ A small amount of steam is generated by some utilities for direct delivery through insulated pipes to customers for heating and air conditioning. Steam generation presents certain problems over and above those associated with electrical generation, namely, that steam generating plants cannot be relocated outside the cities served by them, since the steam cannot be transported over appreciable distances.

Much of the data used herein relates to New York City because this data is readily available to the author.

${ }^{3}$ These figures are based on New York City in 1965 . Percentage ranges for the sulfur content of coal and oil burned by Con Ed are approximated: coal, I-2.5\%; fuel oil, 2.15-2.40\%. Mayor's Task ForcB on Air Poliution in the City of New York, Freedom to Breathe ir7 (r966) [hereinafter cited as TASK FORCE REPORT].

'G. Chalmers, Afr Pollution Control in Solid Waste Management in the New York City Metropolitsn Region, table 2 (Resource Paper prepared for Citizens for Clean Air, Inc., New York City, I968) [hereinafter cited as SoLID WASTE MANAGEMENT REPORT].
} 
contributor of sulfur oxides) is almost nonexistent, the primary problems stems from the community's heavy reliance on the automobile, which produces large quantities of oxides of nitrogen that react with ozone to form a brownish haze over the city. In New York, while nitrogen oxides are a problem, the inordinate quantities of sulfur oxides from space heating, industry, and utilities dominate the pollutant mix.

The physiological harm to the human body from sulfur compounds and particulates is thoroughly documented. ${ }^{\mathbf{5}}$ Oxides of sulfur are emitted into the atmosphere, predominantly as sulfur dioxide; a small percentage is, or is oxidized to, sulfur trioxide, which combines with water vapor in the air to form sulfuric acid. Minute particles of soot in the atmosphere act as condensation nucleii for the oxides and the acid. Respirable because of their size, these carrier particles transport the sulfur compounds into the passages in the lungs, causing pulmonary emphysema as well as lesser lung ailments. The particulates which serve as carriers are generally less than five microns in diameter and are emitted into most urban atmospheres from space heating and industrial plants as well as from power generating utilities. The utilities' contribution to the finer particulates-those especially harmful to healthis moreover greater than their over-all share of net particulate emissions. The reason for this is that relatively efficient control devices on the utilities' stacks preferentially remove larger particles; power plant emissions are consequently entirely in the dangerous under-five-micron range. ${ }^{6}$

Further complicating an analysis of the utilities' contribution to pollution is a lack of understanding of the relationship between emissions and atmospheric concentration. Emissions of a particular pollutant from one kind of source can be measured. However, there is no known method for quantitatively translating an emission from a particular source or type of source into the pollutant concentration in the atmosphere caused directly by that source or source type. Qualitative conclusions, necessarily imprecise, can be drawn but they are not very satisfactory as hard evidence.

Still other factors, none of which are susceptible of mathematically precise description, enter into any attempt to prove or disprove the effect of a utility's emissions on air pollution. Cities often generate atmospheric inversions-a layer of air which traps a bubble of stagnant air beneath it. Utilities usually have high smoke-stacks, and their emissions to some extent "punch through" the inversion layer; to that extent

\footnotetext{
${ }^{B}$ E.g., McCarroll, Measurements of Morbidity and Mortality Related to Air Pollution, a paper presented at the 59th Annual Meeting of the Air Pollution Control Ass'n, San Francisco, Cal., June 20, 1966; Winkelstein, The Relationship of Air Poilution and Economic Status to Total Mortality and Selected Respiratory System Mortality in Men, a paper presented at the American Medical Ass'n Air Pollution Medical Research Conference, Los Angeles, Cal., March 2-4, I966; prepared testimony of Dr. Stephen M. Ayres, Record at 8597-8610, Transcontinental Gas Pipe Line Corp. (Phase II), 38 F.P.C. No. 532, 7 I P.U.R.3d I6I (Nov. 6, 1967). See also Cassell, The Health Effects of Air Pollution and Their Implications for Control, in this symposium, -

${ }^{-}$In the New York City metropolitan area, power plants contribute about 20\% (13,000 tons in x966) of the total particulates but about one-third of the respirable particulates. SoLID WASTE MArAGEMENT REPORT 3.
} 
their emissions do not contribute to the city's pollutant concentration. But the extent of this "punch-through" effect can never be known, even to a good approximation."

The advocate's burden of demonstrating to the FPC that, with all of the above factors considered, the requested certification will have a substantial beneficial impact on the local pollution problem, is not an easy one. Moreover, the art and rules of legal advocacy are not the best tools for arriving at scientific truth. Nevertheless, if sufficient expert opinion is mustered on the side of those seeking the gas, all that the opposition can do is present a negative defense, attempting to show a lack of hard scientific evidence for the experts' conclusions. This is not a very persuasive type of case.

\section{II}

\section{The Scope of the FPC's Jurisdiction Under the Natural Gas Act-} Conservation of Gas and the "End Use" Doctrine

Jurisdiction over interstate transportation and sale of natural gas, bottomed on the Commerce Clause of the Constitution, is granted to the FPC by the Natural Gas Act of $193^{8} .^{8}$ Section $\mathrm{I}$ of the act, defining its scope, provides in part

(a) ... that the business of transporting and selling natural gas for ultimate distribution to the public is affected with a public interest, and that Federal regulation in matters relating to the transportation of natural gas and the sale thereof in interstate and foreign commerce is necessary in the public interest.

(b) The provisions of this chapter shall apply to the transportation of natural gas in interstate commerce, to the sale in interstate commerce of natural gas for resale for ultimate public consumption for domestic, commercial, industrial or any other use, and to natural-gas companies engaged in such transportation or sale. ...

A "natural gas company" is defined by section 2 of the act, as "a person engaged in the transportation of natural gas in interstate commerce, or the sale in interstate commerce of such gas for resale."

The regulatory power of the Commission is comprehensive, extending to rates and classifications; regulations, practices, and contracts affecting rates; extension, improvement, or abandonment of facilities; making connections with customers to be served; and the transportation or sale of gas ${ }^{10}$-all subject to the interstate and foreign commerce restrictions of section $\mathbf{I}(\mathrm{b})$ of the act. ${ }^{11}$ Section 4 empowers the Com-

\footnotetext{
TTheir effect at some distant point downstream from the emission is another matter. E.g., TAss ForCe RePort I2 ("Dirty air drifts into New York from hunidreds of miles away-especially from nearby New Jersey, with its relatively uncontrolled industrial complexes and incinerators.") See note 58 infra.

I5 U.S.C. $\$ 7$ I7 $(1964)$.

Id. $\$ \operatorname{II}(\mathrm{a})(6)$.

${ }^{10} I d$. $\$ \$ 7 \mathrm{I} 7 \mathrm{~d}, 7 \mathrm{If}$. The Commission is empowered to and does delve decply into the cost economics underlying any rate which it may properly regulate.

21 The Commission was not granted comprehensive power over all incidents of gas production, transportation, and sale. Certain incidents were left for state regulation. See Panhandle Eastern Pipe Line Co. v. Public Service Comm'n, 332 U.S. 507, 514 (1947). Its jurisdiction was materially expanded,
} 
mission to review and regulate rates charged by natural gas companies in connection with the transportation or sale of all gas subject to its jurisdiction, and to declare unlawful any rates which are not "just and reasonable."12 Section $7(c)$ requires that $^{13}$

No natural gas company ... shall engage in the transportation or sale of natural gas, subject to the jurisdiction of the Commission, or undertake the construction ... of any facilities therefor, or acquire or operate any such facilities . . . unless there is in force with respect to such natural gas company a certificate of public convenience and necessity issued by the Commission authorizing such acts or operations.

The movement of gas in foreign (as distinguished from interstate) commerce is broadly and simply covered by section 3 of the act, requiring Commission sanction of all exports and imports of natural gas. That sanction is assured unless the export or import would "not be consistent with the public interest."14

This bird's-eye view of the broad federal regulatory power over natural gas, extending to most gas currently being produced, indicates that air pollution considerations might be urged upon the Commission in any number of situations. However, such considerations have figured importantly only in one context-attempts by public utilities to obtain gas as boiler fuel for electrical power generation. Nonboiler-fuel gas intended for-resale by utilities to consumers has been obtained or refused based upon the usual economic and market factors historically relevant to "public convenience and necessity," as that term is used in section 7 of the act. It has apparently not been necessary for petitioners to advance arguments based on air pollution to obtain resale gas, even though such arguments might conceivably be made.

Attempts to obtain boiler fuel gas, however, have run headlong into the FPC's "end use" policy, bottomed on the Commission's asserted duty to conserve gas, a wasting asset, by limiting its expenditure to end uses adjudged to be in the public

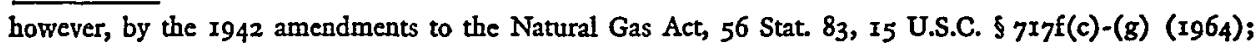
see FPC v. Transcontinental Gase Pipe Line Corp., 365 U.S. I (I96I).

${ }^{12} 15$ U.S.C. $\$ 7$ r 7 c. $\$ \$ 717 c(a)$ and (b) state,

"(a) All rates and charges made, demanded, or received by any natural-gas company for or in connection with the transportation or sale of natural gas subject to the jurisdiction of the Commission, and all rules and regulations affecting or pertaining to such rates or charges, shall be just and reasonable, and any such rate or charge that is not just and reasonable is declared to be unlawful.

“(b) No natural-gas company shall, with respect to any transportation or sale of natural gas subject to the jurisdiction of the Commission, (I) make or grant any undue preference or advantage to any person or subject any person to any undue prejudice or disadvantage, or (2) maintain any unreasonable difference in rates, charges, service, facilities, or in any other respect, either as between localities or as between classes of service."

${ }^{18} I d . \& 7 \mathrm{I} 7 \mathrm{f}(\mathrm{c})$.

${ }^{14} I d . \$ 71 \mathrm{~b}$. Its foreign commerce jurisdiction, insofar as it concernis facilities located at any United States border, is exercised by the Commission in conformity with Exec. Order No. 10,485, 3 C.F.R., 1949I953 Comp., at 970, 15 U.S.C. \$ 717b (1964). 
interest. Such uses are, according to the Commission, those for which no other fuel is equivalent to gas or provides the same technical and economic advantages. Other end uses-including use as boiler fuel-are deemed to be inferior, that is, the necessity to conserve gas outweighs any advantage to be gained from the "inferior" use.

The end use doctrine and its application by the Commission are central to an understanding of past attempts to obtain boiler fuel gas and to the probable outcome of future attempts. The doctrine is not new; decisions of the Commission alluded to and weighed end use beginning as far back as $1944 .^{15}$ There was at that time some question whether matters of conservation, upon which its inquiry into end use is founded, were properly the subject of the Commission inquiry. Conservation was clearly not placed within the Commission's purview by the $193^{8}$ act. ${ }^{18}$ To correct what it believed to be an undesirable limitation, preventing inquiry into the social and economic ramifications of fuel use, the Commission argued as follows:

The Natural Gas Act as presently drafted does not enable the Commission to treat fully the serious implications of such a problem. The question should be raised as to whether the proposed use of natural gas would not result in displacing a less valuable fuel and create hardships in the industry already supplying the market, while at the same time rapidly depleting the country's natural-gas reserves. Although, for a period of perhaps 20 years, the natural gas could be so priced as to appear to offer an apparent saving in fuel costs, this would mean simply that social costs which must eventually be paid had been ignored.

Careful study of the entire problem may lead to the conclusion that use of natural gas should be restricted by functions rather than by areas. Thus, it is especially adapted to space and water heating in urban homes and other buildings and to the various industrial heat processes which require concentration of heat, flexibility of control, and uniformity of results. Industrial uses to which it appears particularly adapted include the treating and annealing of metals, the operation of kilns in the ceramic, cement, and lime industries, the manufacture of glass in its various forms, and use as a raw material in the chemical industry. General use of natural gas under boilers for the production of steam is, however, under most circumstances of very questionable social economy. ${ }^{17}$

The 1942 amendments to the act, enacted at the Commission's urging, ${ }^{18}$ at least partially closed this gap in its regulatory authority. The uncertainty of the impact in this area of the 1942 amendments, however, is illustrated by the fact that in FPC v. Transcontinental Gas Pipe Line Corp. (hereinafter called the $X-20$ case), ${ }^{10}$

\footnotetext{
${ }^{15}$ Memphis Nat. Gas Co., 4 F.P.C. I97 (1944), af'd sub nom. Department of Conservation v. FPC, I48 F.2d 746 (5th Cir. 1945), cert. desied, 326 U.S. 717 (I945).

${ }^{10}$ This was recognized by the Commission in its Annual Report for 1940. 20 FPC ANN. ReP. 79-80 (I940). The r938 act, $\$ 7$ (c), ch. $556, \S 7(\mathrm{c}), 52$ Stat. 825, as amended, I5 U.S.C. $\$ 717 f(c)$ (1964), authorized the Commission to determine public convenience and necessity only in cases where application was made to transport gas into areas already being served by another natural gas company.

IT 20 FPC ANN. ReP. 79 (I940).

${ }^{18}$ H.R. REP. No. I290, 77th Cong., Ist Sess. 3 (194I); S. Rep. No. 948, 77th Cong., 2d Seso. (1942).

${ }_{10}{ }_{365}$ U.S. $\times\left(x_{96} 6 \mathrm{x}\right)$.
} 
which in 196I finally confirmed the legitimacy of the end use doctrine, each successive tribunal decided this question oppositely to the previous one. The Supreme Court ultimately found inquiry into end use by the Commission to be a proper exercise of its duty to consider all factors, including gas conservation, bearing on the public interest. But this, the Court ruled, did not go so far as to empower the Commission "to formulate a flat rule against direct sales [of gas] for use under industrial boilers." ${ }^{20}$ This limitation on its authority appears at least to require the Commission in a section 7 proceeding to examine the particular factors surrounding the end use at issue and to make them part of the equation for determining the public interest. Thus there are no end uses which per se warrant denial of certification; there is no statutory authority for any per se rule based on end use categorizations.

Aside from putting to rest arguments over the extent of the Commission's power to consider end use, the $X-20$ case was the first instance in which air pollution arguments were advanced in an attempt to obtain boiler fuel gas. The precise issue before the Commission and, subsequently, the Court, was whether Transcontinental should be permitted to sell to Con Ed certain gas for use as boiler fuel. Unfortunately (by way of precedent) for those who have since sought to obtain certification of boiler fuel gas, the particular sale proposed by Con Ed was a "direct," or nonjurisdictional, sale. That is, the proposed $X-2 o$ service involved a sale by the producer directly to Con Ed, who then contracted with Transcontinental to have it transported to New York. ${ }^{21}$ This raised in the Commission's mind the spectre of a vast increase in nonjurisdictional sales, over which it exercises no rate-making power, possibly leading to a sizable increase in field prices.

Aside from the jurisdictional factor the Commission's attention was focused primarily on so-called "conventional requirements" of public convenience and necessity. ${ }^{22}$ As the court of appeals' opinion pointed out, this phrase

is a vague one, something like "due process of law," out of which one can get what he cares to put in. It is, obviously, the kind of a phrase where experience through the years builds up criteria which must be met in determining its content. Such experience-built criteria were what the Commission looked at when it saw that the "conventional requirements" for convenience and necessity had been met. ${ }^{23}$

${ }^{30}$ Id, at I7. The Court felt compelled to draw this line because the Commission had admitted a lack of "complete and comprehensive authority" over end uses in its I944 Annual Report to Congress. FPC, The First Five Years UNDER The Naturat Gas Act I5 n.x4 (1944), quoted in 365 U.S. at I5. $_{5}$

${ }^{21}$ A "direct" sale is one in which, as in this case, the contract of sale expressly prohibits the vendec from reselling the gas; the sale is consequently not for resale in interstate commerce and therefore not within the Commission's jurisdiction. As the presiding examiner candidly pointed out, had Con Ed been able to liquefy the gas and ship it to New York other than by pipeline, the entire transaction would have been outside the scope of federal regulation. Transcontinental Gas Pipe Line Corp., 20 F.P.C. 303, 316 (1958).

\footnotetext{
${ }^{22} 2$ I F.P.C. $I_{3} 8, I_{41}$ (I959).

${ }^{38} 27$ I F.2d 942, 946 (3d Cir. r959).
} 
Measured by these conventional tests-adequate gas reserves, adequate market, and sufficient pipeline capacity-the requested service should have (and admittedly would have) been certificated. However, the Commission staff, opposing Transcontinental's application along with economically interested groups, argued that (in addition to being a potential threat to field price structure) burning the gas under utilities' boilers was an "inferior" end use, and further that direct sales of gas to large industrial users would pre-empt pipeline capacity to the detriment of small consumers.

The hearing examiner ruled against the staff, since in his opinion the "policy" arguments underpinning its position were not cognizable by the Commission in a section 7 proceeding. However, he added that if cognizable, they merited a ruling in favor of Transcontinental. The full Commission reversed, holding the policy considerations properly within the scope of a section 7 inquiry. The Supreme Court agreed ${ }^{24}$ finding both the end use and price ${ }^{25}$ factors underlying the staff's arguments proper considerations. Chief Justice Warren, speaking for the Court, explained the rationale of the end use doctrine in the following words:

No one disputes that natural gas is a wasting resource and that the necessity for conserving it is paramount. As we see it, the question in this case is whether the Commission, through its certification power, may prevent the waste of gas committed to its jurisdiction. One apparent method of preventing waste of gas is to limit the [end] uses to which it may be put, uses for which another, more abundant fuel may serve equally well. Thus the Commission in this case, as it often has in the past, has declared that the use of gas under industrial boilers is an "inferior" use, the assumption being that other fuels, particularly coal, are an adequate substitute in areas where such other fuels abound. ${ }^{26}$

The Court rejected arguments that considerations of natural resource conservation had been left by Congress exclusively to the states.

In $X-20$, for the first time, one argument urged upon the Commission was that the requested gas was necessary to combat air pollution. However, the advantage to be gained by certification was merely the removal of a smoke plume from Con Edison's Waterside plant, which blocked the view from the United Nations building. The specific air pollution evidence adduced in $X-20$ was merely thirteen pages of testimony by New York City's Air Pollution Control Commissioner, concluding that there might not even be a causal relationship between emissions from the Waterside station and injury to health. The air pollution considerations of the case were clearly secondary to the basic question of whether the so-called policy considerations raised by the Commission staff were cognizable in a section 7 proceeding, and the

\footnotetext{
${ }^{24}{ }_{365}$ U.S. I (196r). The Court reversed a decision of the court of appeals, which had reversed the Commission.

${ }^{28}$ The "end use" factors were the wasteful use of gas and its pre-emption of pipeline capacity; the "price" factor was that the nonjurisdictional (and therefore non-price-controllable) sale, since it was at a field price higher than that approved by the Commission, would drive the price up generally.

${ }^{10} 365$ U.S. at 8-9.
} 
Supreme Court was concerned with whether the legislative history of the act supported the Commission's authority to examine those considerations. Yet the Supreme Court's approval of the conservation argument in the face of an asserted air pollution problem has remained the nemesis of those seeking gas for the purpose of alleviating air pollution.

\section{III}

Proceedings Before the Commission to Oibtain Boiler Fuel Gas to Allevtate Arr Pollution

In the wake of $X-20$, the Commission has been called upon on three occasions ${ }^{27}$ to certificate gas for boiler fuel in order (among other reasons) to reduce air pollution in the area to be served. Two of these proceedings have involved the country's largest, most populous, and most notoriously polluted cities-New York and Los Angeles. In each of the three cases, the Commission refused to find that the asserted air pollution benefits warranted certification of the requested service. However, in two of the three proceedings the service was certificated on the basis of other considerations. The third case involved the approval of a proposal for the development of the Los Angeles market and the denial of a competing proposal which contemplated substituting gas for other fossil fuels for power generation in order to reduce pollution.

In only two of these three cases was there a relatively complete exposition of (a) the harmful effects of the existing air pollution condition, and (b) the reduction in those harmful effects which the requested gas substitution was expected to bring about. In neither case were the Commission members unanimous in their evaluation of the air pollution evidence of record. Yet examination of the record and the reasoning in both cases indicates that before the Commission will approve a proposal involving increased use of gas for air pollution abatement, it will require the proponents of the proposed service to meet a higher burden of proof than that previously required to justify allocations of gas for other, even "inferior," end uses. In fact, it may not be going too far to suggest that a majority of the Commission would prefer to sweep air pollution under the rug as a factor in determining whether a proposed use is consistent with the present or future public convenience and necessity.

\section{A. The Gulf Pacific Case}

The Commission's first full-scale consideration of air pollution (unlike its brief consideration in $X-20)$ as an attempted justification for obtaining increased quantities

${ }^{27}$ The Los Angeles area was involved in Transwestern Pipeline Co., 36 F.P.C. ${ }_{7} 6$ (x966), rehearing denied, 36 F.P.C. 1010 ( $\mathrm{xg66}$ ) [hereinafter cited as Gulf Pacific]; service to Florida's lower east coast was considered in Florida Gas Transmission Co., 37 F.P.C. 424 (1967); and New York City's air pollution was extensively reviewed in Transcontinental Gas Pipe Line Corp. (Phase II), 38 F.P.C. No. 532, $7 \mathrm{x}$ P.U.R.3d I6I (Nov. 6, I967) [hereinafter cited as Transco]. 
of boiler fuel gas came in Ig66 in the Gulf Pacific case. Gulf Pacific involved two competing proposals for the development for the expanding Los Angeles market, one of which, that of the Gulf Pacific Company, contemplated burning increased quantities of gas under boilers for power generation in order to abate Los Angeles' considerable air pollution. Extensive evidence was received documenting the adverse effects of Los Angeles' particular air contaminants on health and property and the partial alleviation of these effects to be obtained by substituting natural gas for sulfurcontaining fuels. The hearing examiner, deciding that the gas should be granted, concluded that the atmospheric pollution existing in the Los Angeles area presented a "health problem"28 and that

The Los Angeles air pollution problem will not be eliminated by the use of gas under boilers but the reduction in tonnage of pollutants in the magnitude here under consideration will affect the concentration of contaminants and aid in the program of the APCD [Los Angeles county Air Pollution Control District] to reduce air pollution to the benefit of the people in the Los Angeles basin. ${ }^{20}$

On appeal the Commission disagreed. Reviewing the evidence, the Commission concluded that air pollution in Los Angeles did indeed constitute some threat to health but that the evidence was insufficient to draw any conclusions as to the extent of the danger. It stated,

It is plain on this record that Los Angeles has an acute air pollution problem. We also accept the considerable medical evidence that this air pollution may have some deleterious effect upon the health of the residents of Los Angeles as contended by the Los Angeles County Medical Society, the APCD, and others, although the extent of the deleterious effect is a matter of dispute. While common sense tells us that any actual or potential danger from air pollution will be decreased if there is a substantial reduction in the concentrations of pollutants in the Los Angeles atmosphere, our resolution of this issue would be heavily influenced by a clear indication that the existing levels are either well within levels of tolerance or well above such levels. The many health experts who participated in this proceeding have not defined any such standard with respect to the various aspects of the air pollution question with which this record deals, and it does not lie within the competence of this Commission to do so. ${ }^{30}$

The Commission found that the use of greater volumes of natural gas in Los Angeles would not have "an appreciable effect upon the area's smog problem," which it found was the area's major pollution problem. While recognizing the existence of sulfur oxides in Los Angeles' air, the Commission took issue with the alleged severity of the problem, noting that the 0.I ppm (parts per million) level ${ }^{31}$ had been

${ }^{28} 36$ F.P.C. 262, 294 (Initial Decision of the Presiding Examiner, 1965).

${ }^{29}$ Id. at 295.

${ }^{80}$ Id. at $\mathrm{I} 86$. (Emphasis added.)

${ }^{31}$ One-tenth part per million (ppm) is the maximum acceptable level of $\mathrm{SO}_{2}$ concentration according to standards set by the U.S. Department of Health, Education, and Welfare (HEW); this level is not to bo exceeded more than $\mathrm{x} \%$ of the time. See text accompanying note 47 infra. 
exceeded at monitoring stations only a maximum of five days in the four years I960-1963, compared with 42 days in Washington, 75 days in Philadelphia, I86 days in Chicago, and 196 days in New York during 1963 alone. The Commission concluded that

The additional gas would reduce the concentration of sulfur dioxide somewhat but there is no showing that using only gas in power plant boilers would have any beneficial effect on the health of the people of Los Angeles.

We are fully conscious that we are here dealing with an issue of public health which does not lend itself to absolute proof and should not be thought of exclusively in economic terms. Obviously, a showing that additional natural gas for boiler use would reduce air pollution in any significant manner would merit the most serious attention, for this Commission, like the general public, is increasingly concerned about the environment in which we live. Not only has there been no such showing, but under the broad public convenience and necessity requirement of the Natural Gas Act, this factor, as important as it is, cannot be considered in isolation. . . . [W] conceive our responsibilities to be broader and to require a more analytical review of all relevant factors including alternate means of reducing air pollution. ${ }^{32}$

Commissioner O'Connor dissented on the "conventional" ground that the majority decision failed to take into consideration the long-term natural gas needs of the market. His dissent agreed with the majority conclusion that the evidence was insufficient to establish levels at which the various contaminants can be said to be either safe or harmful, but noted that

it did establish that existing levels of air pollution are deleterious to the health of the people of the Los Angeles area. Furthermore, I am convinced that although the reduction in contaminants emitted as a result of the substitution of natural gas for fuel oil will not completely solve the overall air pollution problem, it will, nevertheless, bring about a reasonable reduction and be in consonance with the overall desires and plans of the people of Los Angeles and the Los Angeles APCD.33

Just how extensive a reduction must be brought about in order to warrant certification is a question which the Commission has not yet completely answered.

\section{B. The Florida Gas Case}

The Commission's next hearing on air pollution occurred the following year in Florida Gas, in which the petitioner urged that its "primary reason for entering

${ }^{82} 36$ F.P.C. at $189-90$.

${ }^{33}$ Id. at 228, 256 (dissent). Additionally, with respect to air pollution, Commissioner O'Connor stated,

"When the vast sums of money which have been expended by the taxpayers of southern California for the elimination of the air pollution problem are taken into consideration, it becomes self-evident that their desire for more gas is not so much founded on economic considerations as how to get the greatest supply for the longest period of time. . . . These vast expenditures can only be interpreted as indicating an intense desire of the people of Los Angeles towards curbing the amounts of contaminants emitted daily into the atmosphere regardless of the percentage of the total air pollution problem the offending industries or machines contribute."

Id. at 254 . 
into a contract for additional supplies of natural gas was its desire to alleviate a serious air pollution problem on Florida's lower east coast, which is caused by the burning of high sulfur fuel oil in its electric generating plants."34 Both the presiding examiner and the Commission found deficient the air pollution evidence of record, which consisted largely of theoretical computations of atmospheric sulfur dioxide concentration. The Commission concluded,

While the calculations show that ground level concentrations of $\mathrm{SO}_{2}$ in the vicinity of the Port Everglades, Riviera and Cape-Kennedy plants could exceed one part per million, these studies were theoretical, based upon the burning of fuel and assumptions as to atmospheric conditions, not on actual measurement of $\mathrm{SO}_{2}$ concentrations in the vicinity of the power plants. It seems significant that HEW did not file exceptions [to the Examiner's initial decision]. ${ }^{35}$

The balance of the evidence as to air pollution consisted of complaints, which were almost entirely directed to visible emissions from boiler stacks, and of testimony that certain of the polluting plants were in tourist areas and areas inhabited by elderly and especially sensitive retirees.

Unconvinced by the air pollution evidence, the Commission nevertheless approved the proposal based largely upon its conclusion that the unique nature of the Florida fuel market made it desirable to favor increased industrial consumption of gas. ${ }^{90}$ Whereas the Commission usually viewed the use of natural gas for boiler fuel as an inferior end use, in this case the use was found not to be inferior, based on the nature of the market. In this respect, Florida Gas is exemplary of the Commission's flexibility in analyzing in each case whether, in the particular circumstances present, the use is in the public interest. Unfortunately for advocates of boiler fuel gas as a partial solution to urban air pollution, this flexibility seems to extend only to "conventional" touchstones of public convenience and necessity, stopping short of air pollution. An additional (and "conventional") factor in the Commission's decision was the approximately $\$ 400,000$ net savings to resale customers in Florida.

\section{The "Transco" Case}

The Commission's most recent exposure to arguments based on air pollution was in the Transco case, late in 1967 . At issue was an application to substitute demand service (gas taken directly from the pipeline) for storage service (gas injected into

\footnotetext{
${ }^{84}{ }_{37}$ F.P.C. 466,475 (Initial Decision of the Presiding Examiner, 1966).

${ }^{85}$ Id. at 446 .

so "An important consideration in our decision here flows from the nature of Florida gas operations which we believe is dictated largely by the unique conditions which prevail in the Florida fuel market. As the Commission recognized in 1956, Florida is a fuel deficiency area and must depend almost entirely on imported fuels. This factor, plus the case of transporting natural gas, makes this particular type of arrangement more important there than elsewhere in the country. Because of the mild climate which prevails and the low degree-day deficiency the load factor of any pipeline supplying Florida would be relatively low if it were not for the firm industrial consumption and transportation of gas such as is contemplated here."
}

Id. at 439 . 
underground storage tanks at a constant rate and withdrawn as needed) currently being rendered to Con Ed of New York by Transcontinental Gas Pipe Line Corporation. Approval of the application would have resulted in making increased quantities of natural gas available to Con Ed for power generation in New York City.

Transco was severed from a larger proceeding for the express purpose of permitting a full hearing on the effect of the proposed service on air pollution in New York City. ${ }^{37}$ It resulted in over a week of hearings, ten witnesses, and over 1,000 pages of transcript devoted to the question of the air pollution abatement to be derived from the proposed service. Based upon this evidence, the examiner concluded that New York City's air pollution problem was of "massive proportions"; 38 that the sixteen million people in the greater New York area endure the "greatest concentration of sulfur dioxide of any major city in the country";39 that Con Ed contributed substantially to that concentration; ${ }^{40}$ that the evidence showed a causal relationship between exposure to atmospheric sulfur dioxide and certain serious, sometimes fatal diseases; ${ }^{41}$ and that the proposed service would reduce Con Ed's annual sulfur dioxide emissions by between 22,800 and 25,500 tons, amounting to about four per cent of the city's total emissions. ${ }^{42}$ Despite these findings the examiner denied certification of the proposed service.

At that time New York City was in the initial planning stages of an extensive program to substantially reduce air pollution. As a part of that program the city had recently enacted Local Law I4-Ig66, which required, among other things, a gradual reduction in the sulfur content of fuel burned for power generation down to one per cent sulfur fuel by May I97I. After the record was closed, Con Ed publicly announced that it had made arrangements to obtain by October I, 1967 (four and a half years earlier than required) enough one per cent sulfur-content fuel oil for all of its generating needs, enabling it to halve its sulfur dioxide emissions. Based largely upon this announcement, the examiner denied certification, finding that the use of this newly available low-sulfur fuel would

eliminate the contribution Con Ed has made to New York City sulfur dioxide problem ... [and, therefore,] that no showing has been made that the substitution of natural gas for high-sulfur content oil and coal is required by public convenience and necessity.43

"7 Aligned in favor of the proposed service were the applicant (Transco) and intervenors Con Ed, the U.S. Department of Health, Education and Welfare, and Citizens for Clean Air, Inc. Against the service were Fuels Research Council, Inc., National Coal Association, United Mine Workers of America, and the Commission staff.

ss Presiding Examiner's Initial Decision, Transcontinental Gas Pipe Line Corp. (Phase II), No. CP65-18I (F.P.C., April II, I967) (mimeo. at 24).

${ }^{83} \mathrm{ld}$.

${ }^{10} \mathrm{Id}$.

11 Id. (mimeo. at 42, 43).

4I. (mimeo. at 42).

19 Id. (mimeo. at 4I). In fact, substitution of the gas for $1 \%$ sulfur-content oil and coal would have resulted in the further elimination of between 14,500 and $I r, 100$ tonis of sulfur dioxide. Transco, 7 I P.U.R.3d at 167 . 
The Commission reversed, approving the requested service largely because of "substantial annual savings to Con Ed Company and its customers"44 of approximately $\$ 850,000$ and $\$ 230,758$, compared to the use of oil and coal respectively. The Commission concluded,

We have found Transcontinental Gas Pipe Line Corporation's application to be in the public interest. It has proposed a comparatively modest increase in its firm gas deliveries to Consolidated Edison Company. It has the supplies; there is no question of the market; and the economic feasibility of the transaction is assured."

The air pollution arguments, to which substantial hearing time and large portions of the briefs were devoted, were treated in the Commission's opinion as establishing a convenient but nonetheless superfluous reason for its conclusion. ${ }^{10}$ Specifically addressing itself to the severity of sulfur dioxide levels in New York City, the Commission found,

Both the witnesses for Citizens for Clean Air, Inc. and the Department of Health, Education and Welfare were of the opinion that there is no safe level of sulfur dioxide pollution although the Department of Health, Education and Welfare suggests that the 24-hour concentration in community atmosphere be maintained below to parts per ro0,000,000 i.e., 0.I ppm and that this concentration should not be exceeded more than one per cent of the time. Although there is some controversy regarding the adequacy of the $\mathrm{SO}_{2}$ recording stations, the record clearly shows that the atmosphere in New York does not conform to this standard. ${ }^{47}$

\section{Air Pollution Abatement as a Factor in Public Convenience and Necessity}

The cases discussed above-Gulf Pacific, Florida Gas, and Transco-reveal a trend toward increasingly lengthy assaults upon the Commission to obtain boiler fuel gas for reasons of air pollution abatement. Nevertheless, the FPC has not admitted air pollution to the list of "conventional" criteria which determine public convenience and necessity. This is not to say that the individual commissioners have not given some weight to air pollution abatement in deciding particular cases. It is difficult, for example, after reading the briefs in Transco-all of which were overwhelmingly weighted with air pollution arguments-to accept at face value the Commission's assertion in that case that its decision is based solely on conventional factors. What is clear is that the Commission is highly reluctant to create a

\footnotetext{
"4x P.U.R.3d at $x 65$.

"I Id. at 166 .

"The opinion was subdivided under such headings as "The Conventional Certificate Requirements," and "The New York Air Pollution Problem." Under the latter heading the Commission stated, "Since ... [Transco's proposal] is otherwise supported by the record . . . the effect of this sale on the New York air pollution problem is not controlling. Nevertheless, the serious air pollution in New York may be alleviated slightly by the proposal, and to that extent furnishes an additional benefit." Id.

"7 Id. at 166-67.
} 
precedent by expressly resting a decision granting boiler fuel gas on air pollution benefits. Several factors seem to underlie this reluctance. The prospect of a precedent which opens the door to unknown numbers of applications from communities besieged by real or imagined air pollution may disturb the Commission somewhat. Further, it may be felt that sufficient numbers of these applications would have to be granted once a precedent was set, thus uncomfortably accelerating the rate of gas consumption. And the commissioners may believe that air pollution is a problem which is well on its way to solution by other means and needs no help from them. ${ }^{48}$ Finally, the commissioners may be unwilling to base decisions on scientific facts in unfamiliar fields such as meteorology, public health, medicine, and the chemistry of pollutant compounds.

The Commission's reluctance to rest a decision granting boiler fuel gas on grounds of air pollution abatement has been expressed as an especially high standard (which has never been met) for obtaining boiler fuel gas for that purpose. This standard derives in part from the rebuttable presumption evolved in the 1953 decision in Mississippi River Fuel Corp. ${ }^{49}$ for determining in any case whether to grant natural gas for boiler fuel:

[T] he use of natural gas as boiler fuel is an inferior usage and that, while it is not to be denied in all situations, it should be permitted only on a positive showing that it is required by public convenience and necessity.

The degree of "positiveness" required when the use is justified on air pollution grounds, however, seems to be greater than that required when the justification is on grounds more closely related to the so-called "conventional factors."

Somewhat paradoxically, opinions of FPC examiners have advanced as one reason for denying boiler fuel gas the too-small improvement in pollutant levels to be brought about by the particular quantity of gas requested. Yet if larger quantities of gas are sought for greater impact on pollution, denial based on too rapidly depleting gas reserves is surely to be expected.

The examiner recognized in Transco that "the Commission's boiler fuel policy is not rigid or unyielding. Air pollution, for example, can be an issue of decisive importance if the use of other fuels creates special dangers for a community."50 Yet the Commission's refusal to recognize that pollution in New York City (concededly the nation's worst area in this regard) warranted granting boiler fuel gas may indicate that, at least in the commissioners' minds, such a "community" does not really exist.

\footnotetext{
${ }^{8}$ This view was reflected in a 1966 speech by FPC Chairman Lee C. White. Development of National Policy with Respect to Natural Gas, in Proceedings: The Third National Conference on Air Pollution 137 (Public Health Service Pub. No. 1649 , 1967).

10 I2 F.P.C. I09, II2 (I953).

${ }^{60}$ Examiner's Opinion, supra note 38 (mimeo. at 30 ).
} 
IV

\section{Future Prospects for Obtaining Boller fuel Gas for Air Pollution Abatement}

Given the existing severity of the air pollution problem and the present attitude of the FPC toward allocation of natural gas in its solution, can we expect a change in the availability of boiler fuel gas in the near to medium term? The answer depends largely upon the extent to which power generation from the polluting fossil fuels (i.e., coal and oil) remains a significant part of the total power generation picture. If the economic facts of life tempt the utilities away from the use of coal and oil for boiler fuel either to less polluting fuels or possibly to methods of power production which bypass steam generation altogether, then natural gas will no longer be necessary to displace those fuels. On the other hand, if coal and oil continue to play a significant role in power generation, then worsening atmospheric pollution over metropolitan areas will give rise to increasing pressures on the Commission to channel more gas to boiler fuel use.

Whether or not the Commission can be expected to yield to these pressures will depend in large measure on the gas expenditures likely to be required for air pollution abatement. If the total expenditure is foreseeable and is not overly large in relation to reserves, the Commission is more likely to loosen the reins on boiler fuel gas than if such a move would rapidly or unpredictably accelerate the present rate of increase in gas consumption. Another factor to be considered is whether in the foreseeable future technology will provide economically feasible methods of removing pollutants from stack emissions rendering coal and oil nonpolluting.

Incentives to technological solution of the pollution problem have been considered by the Commission from a different point of view, namely whether granting natural gas in order to abate pollution will remove existing incentives to find other solutions to the problem. In Transco, the hearing examiner speculated,

If more natural gas is used under boilers to aid in licking the air pollution problem, and if as a result natural gas reserves are depleted, what means will later be used to lick the air pollution problem insofar as stack emissions are concerned? Would it be advances in technology?

If necessity is still the mother of invention, would use of more natural gas now as boiler fuel necessarily delay the development of needed additional mechanical devices? ${ }^{51}$

To attempt to answer these questions and to discern what can be expected from the Commission in the way of future allocations of boiler fuel gas, consider the probable medium-term trend of electrical generation. Recent studies indicate that electric power generation will increase about 200 per cent between 1960 and 1980, and

\footnotetext{
${ }^{61}$ Initial Decision of the Presiding Examiner, Columbia Gulf Transmission Co., Docket No. CP65-102 (F.P.C., June $\mathrm{I}_{3}, \mathrm{1966)}$ (mimeo. at 22).
} 
TABLE I

Actual and Projected Electricity Generation by Energy Source, ig60-2000 (Low, Medium, and High Projections)

\begin{tabular}{|c|c|c|c|c|c|}
\hline TOTAL GENERATION: & $\begin{array}{c}1960 \\
(a c t u c x)\end{array}$ & \multicolumn{2}{|c|}{$\begin{array}{c}1980 \\
\text { (projected) }\end{array}$} & \multicolumn{2}{|c|}{$\underset{\text { (projected) }}{2000}$} \\
\hline Hydroelectric (bil. kwh)... & 149 & & 283 & & 363 \\
\hline Nuelear (bil. kwh)... & $3(1963)$ & $\begin{array}{l}\mathrm{L} \\
\mathrm{M}\end{array}$ & $\begin{array}{l}220 \\
400 \\
580\end{array}$ & $\begin{array}{l}\mathrm{L} \\
\mathbf{M}\end{array}$ & $\begin{array}{l}1,230 \\
2,400 \\
3,480\end{array}$ \\
\hline $\begin{array}{l}\text { Conventionsl thermal (bil. kwh) (nat. gas, oil, } \\
\text { coal) } \ldots \ldots \ldots \ldots \ldots \ldots \ldots \ldots \ldots \ldots \ldots \ldots \ldots \ldots \ldots \ldots \ldots \ldots\end{array}$ & 696 & $\begin{array}{l}\frac{\mathrm{L}}{\mathrm{M}} \\
\mathrm{H}\end{array}$ & $\begin{array}{l}1,203 \\
1,546 \\
2,225\end{array}$ & $\begin{array}{l}\mathrm{I} \\
\mathrm{M} \\
\mathrm{H}\end{array}$ & $\begin{array}{l}1,381 \\
1,948 \\
3,924\end{array}$ \\
\hline Total (bil. kwh) .............. & 845 & $\frac{\mathrm{L}}{\mathrm{M}}$ & $\begin{array}{l}1,706 \\
2,229 \\
3,088\end{array}$ & $\begin{array}{l}\mathrm{L} \\
\mathrm{M}\end{array}$ & $\begin{array}{l}2,974 \\
4,711 \\
7,767\end{array}$ \\
\hline $\begin{array}{l}\text { NATURAL GAS DATA: } \\
\text { Gas-based generation (bil. kwh) ........ }\end{array}$ & 181 & $\begin{array}{l}\mathrm{L} \\
\mathrm{M} \\
\mathrm{H}\end{array}$ & $\begin{array}{l}313 \\
402 \\
578\end{array}$ & $\frac{L}{M}$ & $\begin{array}{l}304 \\
429 \\
863\end{array}$ \\
\hline 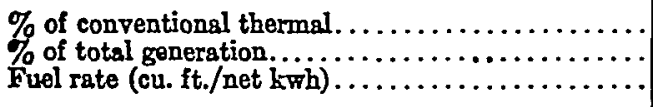 & $\begin{array}{r}26 \% \\
21 \% \\
10,910\end{array}$ & & $\begin{array}{r}26 \% \\
18 \% \\
9,300\end{array}$ & & $\begin{array}{r}22 \% \\
9 \% \\
7,875\end{array}$ \\
\hline Amount consumed (bil. cu. ft.). & 2,034 & $\begin{array}{l}\mathrm{L} \\
\mathrm{M} \\
\mathrm{H}\end{array}$ & $\begin{array}{l}2,998 \\
3,851 \\
5,536\end{array}$ & $\begin{array}{l}\mathrm{L} \\
\mathrm{M} \\
\mathrm{H}\end{array}$ & $\begin{array}{l}2,466 \\
3,479 \\
7,000\end{array}$ \\
\hline
\end{tabular}

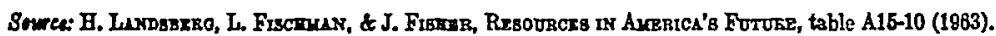

then approximately double between 1980 and $2000 .{ }^{52}$ The corresponding projections for the use of natural gas in electric power generation do not, however, reflect proportional growth. Table I (the medium projections) indicates that consumption of natural gas in electric generation will increase from 2,034 to $3,85 \mathrm{I}$ billion cubic feet between 1960 and 1980 and then fall off to 3,479 billion cubic feet by $2000 .^{53}$ The primary reason for this drop is the expected increase in nuclear generating capacity. Nuclear power costs have come down more rapidly than was projected a few years ago; between fifty and sixty per cent of all electrical power produced is expected to be generated in nuclear installations by the year 2000. Because the bulk of the increase in nuclear generating capacity is expected to occur after 1980 , the demand for all fossil fuels will continue to grow through 1980 , though not as rapidly as the growth of total electric production, since nuclear and hydroelectric

\footnotetext{
6* Federal Power Conom's, National Power Survey 39, 349 (1964); H. Landsberg, L. Fischamann \& J. Fisher, Resources in Ameruca's Future 844 ( 1963 ).

es "Out of such conflicting data one cannot fashion directly any projection of the share that gas is likely to hold of the future utility fuel market. On balance, the use of gas as utility fuel may well be reaching its peak, but its eventual decline, for the reasonis cited, is likely to be slow. The development of percentage shares [in Table $x$ ] reflects this view."

H. Landsberg, L. Fischanan, \& J. Fisher, supta note 52, at 287 . The difficulties involved in making projections for gas use are discussed in $i d$. at $285-88$.
} 
power output are growing even more rapidly. At any rate, there will be a continuing increase during at least the next decade in the quantities of coal and oil burned to generate electricity.

However, the growth of pollution from utilities is not likely to be proportional to the increase in coal and oil consumed by them. Technological progress is being made in solving the emissions problem both $(a)$ by treating the fuel itself to lower its sulfur content, and (b) by cleaning the gases emitted at the stack. In the area of fuel treatment, requirements are being written into state and local air pollution codes which limit the sulfur content of the coal or oil burned. Con Ed, cooperating with New York's Air Pollution Control Department, recently shifted to oil containing a maximum of one per cent sulfur, effecting a reduction of about fifty per cent in the sulfur compounds emitted by it. ${ }^{54}$ The burning in New York City of coal or oil having greater than one per cent sulfur content will be prohibited after May 20, 1971, by existing law. ${ }^{55}$

These factors seemingly presage a significant reduction in sulfur emissons. However, such reduction is largely illusory. For example, no attempts are being made to effect a reduction to one per cent sulfur fuels in the private sector earlier than the 1971 deadline because of fears that low sulfur oil would not be available to fill the resultant demand. Oil which can be processed to lower its sulfur content is presently being imported from South America in limited quantities. Until additional desulfurization equipment is designed and installed at South American refineries, no substantial increase in the availability of one per cent (or lower) sulfur content fuel oil can be expected. And the federal government has been most reluctant to increase import quotas for naturally low-sulfur Arabian crude oil ${ }^{68}$ which (unlike the South American crude oil) requires no desulfurization processing for this application. Further, implementation of air pollution control laws have been beset by endless delays, and it may be longer than expected before they are effective in significantly reducing sulfur emissions.

Emission controls-devices which extract sulfur compounds from the effluent in the stack-are technologically feasible but not yet sufficiently attractive economically to provide a solution. Testifying on this point in Transco, Vernon G. MacKenzie, Chief of the Division of Air Pollution of the U.S. Public Health Service, expressed the opinion that although a number of technologically feasible processes existed for

\footnotetext{
5t The change in fuel sulfur content and the resulting change in sulfur oxide emissions are approximately linearly related. In connection with this discussion of low sulfur oil it is interesting to note the recent discovery of extensive oil fialds in northern Alaska. N.Y. Times, July 28, I968, \$3, at IF, col. I. Preliminary reports suggest that the crude is very high in quality, indicating a low sulfur content. Id., col. 2. If these reports are correct, then the quantity of acceptable low sulfur oil available for use as boiler fucl in metropolitan areas should increase significantly toward the end of the next decade. (Reports indicate that commercial exploitation of these fields is "several years away" pending development of pipeline facilities. Id. at $\mathrm{I}_{4} \mathrm{~F}$, col. 8.)

${ }^{50}$ Local Law No. I4, May 20, 1966, N.Y. CITY ADMIN. CODE $\$ \$ 892-2.0$ to 897-2.0 (Supp. 1967). Section 893-r.o restricts fuel sulfur content and establishes the timetable.

${ }^{8}$ Such a quota increase was recently obtained by Los Angeles for air pollution control.
} 
removing sulfur from combustion gases, it is impossible to predict when (and indeed if) any of those processes would become commercially available. Other witnesses agreed with Dr. MacKenzie that certain existing devices were not suitable for reasons such as lack of space, which apply to any urban center.

In addition to sulfur compound emissions, particulates from utilities' stacks are a serious problem. The technology to solve this problem, however, is largely a reality. Electrostatic precipitators exist which are capable of eliminating over 99.5 per cent of the particulates coming through the stack. The problem is largely one of getting the utilities to install such devices. Con Ed has assertedly found it impossible to upgrade control equipment at many of its plants simply because it lacks sufficient reserve equipment to take the stations off line for upgrading. ${ }^{.7}$ This situation is likely to occur in any number of urban areas as, in the immediate future, increasing population densities bring about more severe pollution problems before the public alarm necessary to reverse the trend can be aroused.

An additional factor tending to postpone the demise of pollutant generation in densely populated areas is associated with the economics of nuclear power plant location. The refusal of the Atomic Energy Commission to approve nuclear generating stations in densely populated urban areas means higher costs for switching to nuclear power in such areas, due to the cost of transmitting the power into the city. It is precisely the large, densely populated urban area in which air pollution is at its worst. This kind of area therefore has the greatest need for nuclear generation; yet the costs for rights-of-way over which power from remote nuclear plants may be supplied to it are extraordinarily high.

Any attempt to project accurately the future contribution to air pollution of fossil fuel power generation based on factors such as those described above must necessarily be imprecise. Further clouding the picture is a startling lack of understanding on how much a utility's emissions, usually sent aloft through high stacks, contribute to ground level pollutant concentration..$^{58}$ It is probably safe to predict, however, that generating utilities will continue to be a major factor in polluting urban atmospheres for five years at the very least, and probably for ten to twenty years to come. The Commission will, therefore, most likely be faced with additional requests for boiler fuel gas over the next several years.

The Commission's fears that in granting such requests it might remove incentives toward technological solutions to the problem seem groundless. The cost of gas to the utility and to the consumer is higher, on a firm basis, than the cost

\footnotetext{
87 TASK Force Report 102, 108.

${ }^{18}$ In New York, Con Ed's 500-foot-high stacks, with still higher "effective stack heights" (an engineering concept which takes into effect the velocity and temperature of the stack gases) may send pollutants up through the inversion layer which ordinarily acts as an atmospheric lid on an urban area. A utility which contributes $50 \%$ of a city's pollutant emissions thus does not necessarily contribute $50 \%$ of its pollutant concentrations. No means is known for quantitatively translating per cent of emission into per cent of concentration. And no one can guess the effect of the emission which "punches through" the inversion layer on the municipalities downwind.
} 
of coal or oil. To continue to purchase these lower cost fuels, ${ }^{60}$ as well as to avoid dependence on any single fuel, it will be necessary to engage in research to learn how to burn coal and oil without polluting the environment. Attempts to recover sulfur from stack gases will continue so long as there exists the economic incentive of a valuable sulfur yield. Solutions which envisage refining oil to a lower sulfur content are being explored by oil companies, whose market for the low sulfur product will be much broader than the utilities. This market will no doubt be largely enhanced, if not created, by legislation to limit the sulfur content of fuels.

Returning to the question of whether the Commission is likely to reverse its stand on boiler fuel gas, it is informative to inquire how adequate are our natural gas resources and what impact on them such a reversal might have. During the last ten years, ${ }^{60}$ net gas reserves have continued to increase at an average rate of roughly five billion Mcf. (thousand cubic feet) annually (Table 2). Since 1945, newly discovered reserves have been greater each year than net gas production. From 1945 to 1966 new reserves have exceeded net production by over I3.9 trillion cubic feet-equal to eight years' supply at the present rate of consumption. ${ }^{01}$ In 1966 proven recoverable reserves-an accepted measure of available gas-stood at a high of 289.3 trillion cubic feet, ${ }^{82}$ leaving more than $x 6.5$ years of proven reserves

\section{TABLE 2}

Summary of Annual Estimates of Natural Gas Reserves, 1945-1966

Note: Volumes are calculated at a pressure base of $14.73 \mathrm{psi}$, 2bsolute, and at a standard temperature of $60^{\circ} \mathrm{F}$.

(Millions of cubic fect)

\begin{tabular}{|c|c|c|c|c|c|c|c|}
\hline \multirow[b]{2}{*}{ Year } & \multicolumn{3}{|c|}{ Natural Gas added during year } & \multirow[b]{2}{*}{$\begin{array}{l}\text { Net Change } \\
\text { in } \\
\text { Onderground } \\
\text { Stcrage }\end{array}$} & \multirow[b]{2}{*}{$\begin{array}{c}\text { Preliminary } \\
\text { Net } \\
\text { Production } \\
\text { during } \\
\text { Year }\end{array}$} & \multirow[b]{2}{*}{$\begin{array}{l}\text { Estimated } \\
\text { Proved } \\
\text { Reserve as of } \\
\text { End of Ycar }\end{array}$} & \multirow[b]{2}{*}{$\begin{array}{l}\text { Inarcase } \\
\text { over } \\
\text { Provious } \\
\text { Ycar }\end{array}$} \\
\hline & $\begin{array}{l}\text { Extensions } \\
\text { snd } \\
\text { Rerisions }\end{array}$ & $\begin{array}{l}\text { Discoveries of } \\
\text { New Fields } \\
\text { and New } \\
\text { Pools in } \\
\text { Old Fields } \\
\end{array}$ & $\begin{array}{c}\text { Total of } \\
\text { Discoveries, } \\
\text { Revisions and } \\
\text { Extensions }\end{array}$ & & & & \\
\hline 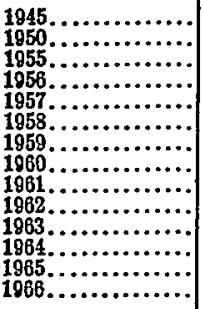 & $\begin{array}{r}9,122,568 \\
16,209,610 \\
19,110,250 \\
11,057,936 \\
13,316,094 \\
14,852,007 \\
7,293,016 \\
10,258,693 \\
13,184,795 \\
12,586,733 \\
13,342,837 \\
14,775,570 \\
14,162,707\end{array}$ & $\begin{array}{l}\mathbf{2}, 861,724 \\
\mathbf{5}, 683,009 \\
\mathbf{5}, 605,864 \\
\mathbf{8}, 950,119 \\
\mathbf{5}, 580,624 \\
\mathbf{5}, 769,245 \\
\mathbf{6}, 600,963 \\
6,907,729 \\
6,299,164 \\
\mathbf{5}, 577,934 \\
\mathbf{6}, 909,301 \\
\mathbf{6}, \mathbf{5 4 3}, 709 \\
\mathbf{6}, 057,725\end{array}$ & $\begin{array}{l}11,984,290 \\
21,897,619 \\
24,716,114 \\
20,008,055 \\
18,896,718 \\
20,621,252 \\
13,893,979 \\
17,16,422 \\
19,483,959 \\
18,164,687 \\
20,252,138 \\
21,319,279 \\
20,220,432\end{array}$ & $\begin{array}{r}54,006 \\
87,161 \\
133,242 \\
178,757 \\
55,588 \\
160,450 \\
281,272 \\
15,254 \\
159,230 \\
253,733 \\
195,111 \\
150,483 \\
134,523\end{array}$ & $\begin{array}{r}6,855,244 \\
10,063,167 \\
10,848,685 \\
11,439,800 \\
11,422,651 \\
12,373,063 \\
13,019,356 \\
13,378,649 \\
13,637,973 \\
14,546,025 \\
15,347,028 \\
16,252,293 \\
17,491,073\end{array}$ & $\begin{array}{l}146,986,723 \\
184,554,745 \\
222,492,644 \\
238,483,216 \\
245,230,137 \\
252,761,792 \\
201,170,431 \\
262,326,326 \\
260,273,642 \\
272,278,858 \\
276,151,233 \\
281,251,454 \\
280,468,023 \\
289,332,805\end{array}$ & 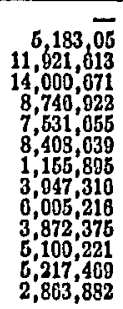 \\
\hline
\end{tabular}

Source: Coumitieg on Naturas Gas Regerves, Amebican Gas Ags'N, Gas Facts 13 (1966).

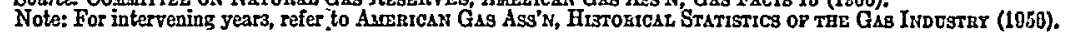

${ }^{50}$ FPC Chairman Lee C. White stated recently, "In the absence of end-use controls or other restrictions, it may be presumed that utilities and other firms which choose to use coal or oil rather than gas when it is available do so because these fuels are less expensive or otherwise preferable." White, supra note 48 , at 140 .

${ }^{\circ}$ Statistics are not available later than 1966 ; all data on gas reserves and usage are taken from American Gas Ass'i Gas Facts (1966) (published annually).

${ }^{61} I d$. at I2.

'Id. at 5 . 
at the present rate of production even if no additional reserves are found. It has been estimated ${ }^{63}$ that the total recoverable gas reserves in the United States are in the neighborhood of $\mathrm{I}, 400-\mathrm{I}, 700$ trillion cubic feet, enough to last more than eighty years at the $I g 66$ consumption rate and more than fifty years at the rate projected for the year $2000 .^{64}$

Given the rate of technological progress during the last several decades, it is probable that radically new energy sources will be developed to the point of economic feasibility well within the next few decades. The members of the FPC are not unaware of this fact. The Commission's Chairman, Lee C. White, stated in Ig66,

History has shown the remarkable success of science in avoiding resource scarcities by discovering new products and production techniques. There are numerous examples of resources which were replaced by better products long before they were exhausted, and therefore, "saving for the future need" can mean sacrificing for a contingency which never arrives. One of the saddest imaginable prospects for our civilization would be to succumb to pollution while "saving" our natural gas for a future generation that would never be born. Examples of resource waste by too rapid consumption (gas flaring, or wildlife and redwood destruction, for example) are also obvious, and perhaps emotionally more striking. History, then, gives us no clear guide. The "best" rate of gas consumption is an elusive target, but one society must consider when it contemplates large shifts in use among the fossil fuels. ${ }^{65}$

There would seem to be little cause, then, to fear that a change in the Commission's policy regarding boiler fuel gas for air pollution abatement could seriously threaten this country's gas reserves. ${ }^{68}$ Even more imminent than the development of new energy sources is the virtual certainty in the author's opinion that, at least within a twenty-year period, adequate methods of cleaning up the effluents from coal and oil thermoelectric generation will have become commercially feasible. Thus, the Commission has no cause to fear that by changing its policy on boiler fuel gas for air pollution abatement it will expose our gas reserves to a never-ending, evergrowing drain. On the contrary, the demand for boiler fuel gas for this purpose should be self-limiting as other nonpolluting methods of obtaining electricity are introduced.

\section{ConCLUSION}

The nonexistence of any real threat to reserves from allocations of gas to boiler fuel use, together with the continuing need for gas for this purpose over the next ten

\footnotetext{
${ }^{\circ} \mathrm{Ild}$.

ou Total annual gas production in the United States in 2000 is estimated at 26.6 trillion cubic feet.

${ }^{00}$ White, supra note 48 , at $14 \mathrm{I}$.

${ }^{80}$ In Transeo, the Commission staff introduced evidence showing the potential expansion in the natural gas market if end use restrictions were eliminated. It showed 2 potential increase of $17 \%$, assuming the admittedly improbable switchover of all significant steam-electric generating plants in "major metropolitan areas"-areas having either populations of over 500,000 or in excess of 40,000 employees in manufacturing industries-to natural gas.
} 
years, indicate at least the possibility that the Commission can be persuaded to view requests for such gas more charitably than it has in the past. A shift in attitude of this nature could occur with no change whatsoever in the legal rhetoric presently employed by the Commission in its opinions. All that is necessary is to find in any given case "a positive showing" that public convenience and necessity would be served by certification of the proposed service, as required by Mississippi River Fuel Corp. ${ }^{87}$ Any thoughts presently held by members of the Commission that power generation will soon cease to contribute to air pollution, without action on its part, must be dismissed as utopian. As research leads to more accurate ways of measuring the effects of utilities on atmospheric pollutant concentration (as opposed to emission levels) and to more complete data on the social, medical, and economic costs of air pollution, it will become increasingly difficult for the Commission to overlook the need for boiler fuel gas in alleviating pollution. It will also become increasingly difficult to justify granting boiler fuel gas on economic grounds, as the Commission did in Transco, where it found that savings to Con Ed and its customers of between $\$ 230,000$ and $\$ 850,000$ justified approval of the proposed services. The reason for this is that a party seeking boiler fuel gas in the future will be able to argue more convincingly than is now possible that the direct economic savings from the reduction in pollution to be achieved matches the dollar savings generally considered by the Commission to justify allocating gas to an inferior end use. Short of this degree of economic preciseness, however, as the need for boiler fuel gas for air pollution abatement becomes more pronounced and as scientific data continues to document the effects of the utilities' emissions on health and property, there is reason to believe that the Commission may look with greater favor on expending limited quantities of natural gas as a partial interim solution to the self-made ecological disturbances that man is only beginning to understand.

\footnotetext{
${ }^{87}$ I2 F.P.C. I09 (1953); see text accompanying note 49 supra.
} 